\title{
Article \\ Tribological Behavior of Aluminum Hybrid Nanocomposites Reinforced with Alumina and Graphene Oxide
}

\author{
Abdul Samad Mohammed 1,2,*D, Omar Saad Aljebreen ${ }^{1}$, Abbas Saeed Hakeem ${ }^{3}\left(\mathbb{D}\right.$, Tahar Laoui ${ }^{4}$, \\ Faheemuddin Patel ${ }^{1}$ (D) and Mirza Murtuza Ali Baig ${ }^{1}$ (D)
}

1 Department of Mechanical Engineering, King Fahd University of Petroleum and Minerals, Dhahran 31261, Saudi Arabia; g201519830@kfupm.edu.sa (O.S.A.); faheemmp@kfupm.edu.sa (F.P.); mmurtuza@kfupm.edu.sa (M.M.A.B.)

2 Interdisciplinary Research Center for Advanced Materials, King Fahd University of Petroleum and Minerals, Dhahran 31261, Saudi Arabia

3 Interdisciplinary Research Center for Hydrogen \& Energy Storage (IRC-HES), King Fahd University of Petroleum \& Minerals, Dhahran 31261, Saudi Arabia; ashakeem@kfupm.edu.sa

4 Department of Mechanical and Nuclear Engineering, University of Sharjah, Sharjah P.O. Box 27272, United Arab Emirates; tlaoui@sharjah.ac.ae

* Correspondence: samad@kfupm.edu.sa

Citation: Mohammed, A.S.;

Aljebreen, O.S.; Hakeem, A.S.; Laoui, T.; Patel, F.; Ali Baig, M.M. Tribological Behavior of Aluminum Hybrid Nanocomposites Reinforced with Alumina and Graphene Oxide. Materials 2022, 15, 865. https:// doi.org/10.3390/ma15030865

Academic Editor: Andrzej Dziedzic

Received: 30 December 2021

Accepted: 20 January 2022

Published: 23 January 2022

Publisher's Note: MDPI stays neutral with regard to jurisdictional claims in published maps and institutional affiliations.

Copyright: (C) 2022 by the authors. Licensee MDPI, Basel, Switzerland. This article is an open access article distributed under the terms and conditions of the Creative Commons Attribution (CC BY) license (https:// creativecommons.org/licenses/by/ $4.0 /)$.

\begin{abstract}
Due to rapid technological advancements, the demand for lightweight materials with improved tribo-mechanical properties is continuously growing. The development of composite materials is one of the routes taken by researchers to meet these target properties. Aluminum (Al) is one of the most suitable materials used for developing composites for a wide range of applications because of its light weight, high conductivity, and high specific strength. In this study, aluminum hybrid nanocomposites with alumina $\left(10 \mathrm{Vol}_{\%} \mathrm{Al}_{2} \mathrm{O}_{3}\right)$ and varying loadings of graphene oxide $(0.25$, 0.5 and $1 \mathrm{wt} \% \mathrm{GO}$ ) were fabricated using the spark plasma sintering technique. The tribological properties of the developed hybrid composites were evaluated by conducting ball-on-disk wear tests at a normal load of $3 \mathrm{~N}$, with a sliding speed of $0.1 \mathrm{~m} / \mathrm{s}$, and for a sliding distance of $100 \mathrm{~m}$. A $440 \mathrm{C}$ hardened stainless steel ball with a diameter of $6.3 \mathrm{~mm}$ and a hardness of $62 \mathrm{RC}$ was used as a counterface. Scanning electron microscopy (SEM), elemental X-ray dispersive analysis (EDS), and optical profilometry were used to ascertain the involved wear mechanisms. The results revealed that $\mathrm{Al}-10 \mathrm{Vol} \% \mathrm{Vol} \% \mathrm{Al}_{2} \mathrm{O}_{3}-0.25 \mathrm{wt} \%$ GO hybrid nanocomposite showed an increase of $48 \%$ in the hardness, a reduction of $55 \%$ in the specific wear rate, and a reduction of $5 \%$ in COF compared with pure aluminum.
\end{abstract}

Keywords: aluminum hybrid composites; alumina; graphene oxide; tribology

\section{Introduction}

The demand for lightweight and high strength materials has been on the rise, primarily due to an expansion of the aerospace and automobile industries [1-5]. Metallic materials are used extensively in various engineering applications for their excellent mechanical and thermal properties. However, they suffer from two major drawbacks, such as high wear and low corrosion resistance. Hence, as the world is moving towards more industrialization, an emphasis on energy conservation has led to many researchers looking for avenues to further improve the properties of metals with a special focus on improving the tribological and anti-corrosive properties of metals. However, the inadequacy of metals and alloys in providing both high strength and stiffness required for demanding engineering applications, coupled with two major drawbacks such as high wear and low corrosion resistance, has led to the development of metal matrix composites (MMCs). Metal matrix composites can be designed to possess qualities such as a low coefficient of friction, low wear, and good anti-corrosive properties, making them suitable for use in demanding engineering applications [6]. 
Aluminum is one of the lightweight materials extensively studied over the years because of its excellent thermal conductivity and high strength-to-weight ratio [7]. However, the use of pure $\mathrm{Al}$ is generally limited to simple engineering applications, which necessitated the development of aluminum-based alloys with enhanced mechanical, corrosion, and tribological properties for a wider range of applications [8-11]. Further improvements to the properties of aluminum-based materials were achieved through the development of aluminum metal-based matrix composites (Al-MMCs) by adding different reinforcements to achieve tailored property combinations $[12,13]$. Ceramic reinforcements such as silicon carbide [14-16], titania [17], alumina [18-22], a combination of different ceramics [23], and carbon-based materials such as carbon fibers [24,25], graphite [26,27], carbon nanotubes (CNTs) [28,29], graphene [30,31], and graphene oxide (GO) [32,33] were used as reinforcements to fabricate Al-MMCs with improved properties.

Aluminum possesses high corrosion resistance under the majority of service conditions but has inferior resistance to wear. This has prompted researchers to develop Al-MMCs with improved tribological properties by incorporating different ceramic and carbon-based reinforcements by employing various fabrication methods. Irrespective of the fabrication process, tribological properties of Al-MMCs with single reinforcement showed improvement over pure aluminum and its alloys, and hybrid reinforcement demonstrated better tribological properties over single reinforcement [34]. Al-MMCs prepared by incorporating $5 \mathrm{wt} \%$ of $\mathrm{B}_{4} \mathrm{C}$ particles as reinforcement using the stir casting method showed improved tribological properties. Sliding wear rate and coefficient of friction were found to increase with the load but decrease with velocity and sliding distance [35]. Stir cast Al-MMCs prepared with $0.5,1,1.5,2$ and $2.5 \mathrm{wt} . \%$ nano silicon carbide powder as reinforcement showed a reduction in wear rate and friction coefficient with increasing SiC content. This was attributed to the increase in hardness and the lubricating nature of the $\mathrm{SiC}$ particles that became detached and polished the worn-out surface of the samples [36]. Wear behavior of $\mathrm{Al}_{2} \mathrm{O}_{3}$ nanoparticles reinforced Al-MMCs prepared using the ultrasonic-assisted semisolid stirring (UASS) method showed a progressive decrease in wear rate with an increase in reinforced $\mathrm{Al}_{2} \mathrm{O}_{3}$ content from $1 \%$ to $7 \%$; however, wear rate increased with $10 \% \mathrm{Al}_{2} \mathrm{O}_{3}$ content, which was attributed to an increase in agglomeration of $\mathrm{Al}_{2} \mathrm{O}_{3}$ nanoparticles [37]. A similar improvement in the wear resistance was observed in studies with $\mathrm{Al}_{2} \mathrm{O}_{3}$ and $\mathrm{ZrO}_{2}$ nanoparticles as reinforcements to Al-MMCs prepared using uniaxial compaction followed by sintering. The improvement in wear resistance correlated with the increase in hardness, owing to the hardness of the ceramic particle reinforcements [38,39]. The effect of hybrid ceramic reinforcements on the tribological behavior of Al-MMCs was also investigated. Hybrid SiC-TiC-Al-MMCs prepared using liquid stir casting process showed an improvement in wear resistance with an increase in the TiC reinforcement content from 1 to $2.5 \mathrm{wt} \%$, whereas $\mathrm{SiC}$ content was fixed at $1 \mathrm{wt} \%$ [40]. Al-MMCs prepared using carbon-based materials as reinforcements were shown to affect tribological behavior. AlMMCs prepared using the spark plasma sintering (SPS) process with $2 \mathrm{Vol} \% \mathrm{Vol} \%$ graphene nanoplatelets (GNPs) showed a lower coefficient of friction but increased wear rate under room temperature and at $200{ }^{\circ} \mathrm{C}$ wear testing. The decrease in the coefficient of friction was attributed to the slippage of interlayers of GNP. In contrast, the poor wear resistance was attributed to the agglomeration of GNPs, which resulted in poor densification and insufficient sintering [41]. However, it was found that the addition of graphite particles as a reinforcement to SiC-graphite-reinforced hybrid Al-MMCs led to the reduction in friction coefficient and frictional heat produced during sliding wear due to the formation of solid lubrication film [42]. The addition of ceramic reinforcements to Al-MMCs was shown to affect the corrosion behavior as well. Al-MMCs prepared with $\mathrm{SiC}$ reinforcements produced by uniaxial compaction and hot extrusion showed improved corrosion resistance upon increasing $\mathrm{SiC}$ content and was attributed to the chemical inertness of $\mathrm{SiC}$ particles to a corrosive solution. Moreover, $\mathrm{SiC}-\mathrm{Al}-\mathrm{MMC}$ exhibited higher wear resistance and lower friction coefficients when wear-tested under corrosive media as compared with pure aluminum [43]. 
From the above literature, it is clear that the addition of ceramic reinforcement, as well as the addition of carbon reinforcement, tends to affect the tribological behavior of the developed Al-MMCs. Moreover, the type of processing method affects the developed properties. Few studies were reported on aluminum composites reinforced with either $\mathrm{Al}_{2} \mathrm{O}_{3}$ or graphene nanoplatelets individually. The present work reports on the synthesis, mechanical properties, and tribological behavior of aluminum hybrid nanocomposites reinforced with $\mathrm{Al}_{2} \mathrm{O}_{3}$ and $\mathrm{GO}$, prepared using the spark plasma sintering process.

\section{Materials and Methods}

Aluminum (Al) powder from the Alpha chemical company, Dartmouth, Canada, with a purity of $99.5 \%$ and an average particle size of $30 \mu \mathrm{m}$ was used as the matrix material. Aluminum oxide $\left(\mathrm{Al}_{2} \mathrm{O}_{3}\right.$ : Purity of $99.88 \%$, particle size of $300 \mathrm{~nm}$, approximate surface area of $85-115 \mathrm{~m}^{2} / \mathrm{g}$ ) was procured from Union Carbide Corporation for BUEHLER Ltd. Lake Bluff, IL, USA and used as the first reinforcement. Graphene oxide (GO) from the AD Nano Company, Shimoga, India, with $99 \%$ purity and surface area of $250 \mathrm{~m}^{2} / \mathrm{g}$ was used as the second reinforcement.

\subsection{Fabrication of the Hybrid Nanocomposites}

In a previous study [44], the $\mathrm{Al}_{2} \mathrm{O}_{3}$ content in the $\mathrm{Al}$ matrix in terms of density and hardness and GO content in terms of mechanical and thermal properties was comprehensively optimized. It was observed that $\mathrm{Al}-10 \mathrm{Vol} \% \mathrm{Vol} \% \mathrm{Al}_{2} \mathrm{O}_{3}$ resulted in the highest hardness of $55.8 \mathrm{HV}$ compared with the other tested loadings of 20 and $30 \mathrm{Vol} \% \mathrm{Vol} \%$, respectively. The improvement in the properties of $\mathrm{Al}-10 \mathrm{Vol} \% \mathrm{Vol} \% \mathrm{Al}_{2} \mathrm{O}_{3}$ was attributed to the uniform dispersion of $\mathrm{Al}_{2} \mathrm{O}_{3}$ within the $\mathrm{Al}$ matrix, as observed from the scanning electron microscopy images. Moreover, among the hybrid nanocomposites, Al-10 Vol\% $\mathrm{Al}_{2} \mathrm{O}_{3}-0.25 \mathrm{wt} \% \mathrm{GO}$ exhibited the highest hardness of $63 \mathrm{HV}$, the highest compressive strength of $180 \mathrm{MPa}$, and the lowest thermal expansion of $14.82 \mathrm{ppm}{ }^{\circ} \mathrm{C}^{-1}$ compared with the pristine and $\mathrm{Al}-10 \mathrm{Vol} \% \mathrm{Al}_{2} \mathrm{O}_{3}$ samples. Since the mechanical and thermal properties of the $\mathrm{Al}-10 \mathrm{Vol} \% \mathrm{Al}_{2} \mathrm{O}_{3}-\mathrm{X}$ wt $\%$ GO hybrid nanocomposites were comprehensively evaluated in [44], the aim of the present study was defined as the evaluation of tribological properties of $\mathrm{Al}-10 \mathrm{Vol} \% \mathrm{Al}_{2} \mathrm{O}_{3}-\mathrm{X} \mathrm{wt} \% \mathrm{GO}$, wherein $\mathrm{X}$ represents the different GO loadings $(0.25,0.5$ and $1 \mathrm{wt} \%$ ) in the hybrid nanocomposite. The detailed procedure of preparing the hybrid nanocomposites, including the ball milling parameters and the spark plasma sintering parameters, can be found in the earlier research [44] and is also described below briefly.

\subsubsection{Sonication and Ball Milling to Disperse and Mix the Powders}

To obtain a uniform dispersion, $10 \mathrm{Vol}_{\%} \mathrm{Al}_{2} \mathrm{O}_{3}$ nanoparticles were sonicated in ethanol for $1 \mathrm{~h}$ using a probe sonicator (Sonics VCX 750, Newtown, CT, USA) with a cycle amplitude of $45 \%$ (ON: $20 \mathrm{~s} /$ Off $5 \mathrm{~s}$ ) at room temperature. The same procedure was repeated for breaking the agglomeration in GO. The dispersed $\mathrm{Al}_{2} \mathrm{O}_{3}$ was then added to the weighed quantity of $\mathrm{Al}$ powder for ball milling (HD/HDDM/01, Union process, Inc., Akron, $\mathrm{OH}$, USA) in zirconia vials. Ball milling was carried out for $24 \mathrm{~h}$ at a rotational speed of $200 \mathrm{rpm}$, using zirconia balls (diameter $=5 \mathrm{~mm}$ ) with a ball to powder ratio of 10:1 for homogeneous mixing. The milling process was carried out in an argon atmosphere to avoid oxidation of the powders and in the presence of $50 \mathrm{~mL}$ of ethanol to avoid any cold welding during the process. The mixed powders were then dried in an oven at a temperature of $80{ }^{\circ} \mathrm{C}$ for $12 \mathrm{~h}$ to evaporate ethanol completely. To prepare the hybrid powders, GO was added in different percentages of $0.25,0.5$, and $1 \mathrm{wt} \%$, respectively, to the mixture of $\mathrm{Al}-10 \mathrm{Vol} \%$ $\mathrm{Al}_{2} \mathrm{O}_{3}$ and mixed for $24 \mathrm{~h}$ with the same milling parameters.

\subsubsection{Spark Plasma Sintering Process}

Circular samples of $20 \mathrm{~mm}$ diameter and a thickness of $6 \mathrm{~mm}$ for each formulation were produced using spark plasma sintering (SPS) equipment (SPS FCTsystem GmBH, 
Frankenblick, Germany) under a high vacuum. Table 1 shows the SPS parameters used for fabricating the samples.

Table 1. Spark plasma sintering parameters used for fabricating the hybrid composite samples.

\begin{tabular}{cc}
\hline Die Material & Graphite \\
\hline Die diameter & $20 \mathrm{~mm}$ \\
\hline Temperature & $550^{\circ} \mathrm{C}$ \\
\hline Heating rate & $200^{\circ} \mathrm{C} / \mathrm{min}$ \\
\hline Holding time (t) & $10 \mathrm{~min}$ \\
\hline Pressure (Pr.) & $50 \mathrm{MPa}$ \\
\hline
\end{tabular}

\subsection{Densification and Hardness Measurements}

The density of the fabricated samples was measured by immersing the sample in deionized water according to Archimedes principles and rule of mixtures by using (Kern ABT weighing scale, 320 g capacity, Nordrhein-Westfalen, Germany). The hardness was measured using a Zwick hardness tester by using an applied load of $500 \mathrm{gf}$. An average of 10 readings is reported for each sample.

\subsection{Friction and Wear Tests}

Ball on disk wear experiments were conducted using a tribometer (UMT-3, Bellerica, MA, USA) to determine the friction and wear characteristics of the composites. The counterface used was a $440 \mathrm{C}$ stainless steel ball with a diameter of $6.3 \mathrm{~mm}$ and a hardness of $62 \mathrm{RC}$. Wear tests were conducted at a normal load of $3 \mathrm{~N}$, with a sliding peed of $0.1 \mathrm{~m} / \mathrm{s}$ for 5000 cycles corresponding to a sliding distance of $100 \mathrm{~m}$. The wear volume loss was estimated using a 3D optical profilometer (GTK-A, Bruker, Bellerica, MA, USA). A scanning electron microscope (SEM: Tescan VEGA ${ }^{3}$, Brno, Czech Republic) with an electron X-ray dispersive (EDS) attachment was used to ascertain the involved wear mechanisms and the role of the wear debris particles. An optical microscope was used to record the counterface ball images to evaluate its wear.

\section{Results}

\subsection{Density and Hardness of the Nanocomposites}

Table 2 shows the densification of all the formulations, measured based on the Archimedes method. It was observed that the density of the samples reduced marginally with the addition of the reinforcements, with pure aluminum showing the highest density of $99.8 \%$ compared with the other compositions.

Table 2. Densification of all the sintered samples.

\begin{tabular}{cc}
\hline Sample & Relative Density (\%) \\
\hline $\mathrm{Al}$ & 99.8 \\
\hline $\mathrm{Al}-10 \mathrm{Vol} \% \mathrm{Al}_{2} \mathrm{O}_{3}$ & 99.5 \\
\hline $\mathrm{Al}-10 \mathrm{Vol} \% \mathrm{Al}_{2} \mathrm{O}_{3}-0.25 \mathrm{wt} \% \mathrm{GO}$ & 98.9 \\
\hline $\mathrm{Al}-10 \mathrm{Vol} \% \mathrm{Al}_{2} \mathrm{O}_{3}-0.5 \mathrm{wt} \% \mathrm{GO}$ & 98.6 \\
\hline $\mathrm{Al}-10 \mathrm{Vol} \% \mathrm{Al}_{2} \mathrm{O}_{3}-1 \mathrm{wt} \% \mathrm{GO}$ & 97.4 \\
\hline
\end{tabular}

Figure 1 shows the hardness variation with the addition of $\mathrm{Al}_{2} \mathrm{O}_{3}$ and $\mathrm{GO}$ to the $\mathrm{Al}$ matrix. It can be observed from Figure 1 that the hardness increased significantly with the addition of $\mathrm{Al}_{2} \mathrm{O}_{3}$ from $32.80 \mathrm{HV}$ to $55.83 \mathrm{HV}$. This is attributed to the inherent hardness of the $\mathrm{Al}_{2} \mathrm{O}_{3}$ particles and their uniform dispersion within the $\mathrm{Al}$ matrix, as reported in the earlier study [44]. Moreover, with the addition of $0.25 \mathrm{wt} \%$ of GO to the Al-10 Vol\% 
$\mathrm{Al}_{2} \mathrm{O}_{3}$ composite, the hardness increased to $63.57 \mathrm{HV}$, after which the hardness decreased with increasing GO content. The increase in hardness with the addition of $0.25 \mathrm{wt} \%$ GO was attributed to the uniform dispersion of both fillers within the aluminum matrix without the formation of agglomerates. Moreover, evidence from the SEM images of the microstructure analysis of $\mathrm{Al}-10 \mathrm{Vol} \% \mathrm{Al}_{2} \mathrm{O}_{3}-0.25 \mathrm{wt} \% \mathrm{GO}$ showed a very fine grain size which contributed to the increase in the hardness. However, the reduction in hardness of the hybrid composites with an increase in the content of GO was attributed to the formation of agglomerates and lower densification of the samples (Table 2) [44]. The variation of hardness with the addition of only $\mathrm{GO}$ and $\mathrm{Al}_{2} \mathrm{O}_{3}$ can also be seen from Figure 1. Clearly, the addition of $0.25 \mathrm{wt} \%$ GO resulted in a marginal increase in hardness compared with the addition of $\mathrm{Al}_{2} \mathrm{O}_{3}$ nanoparticles. This indicates that $\mathrm{Al}_{2} \mathrm{O}_{3}$ reinforcement is the main contributor for the improvement in the hardness of the hybrid nanocomposite.

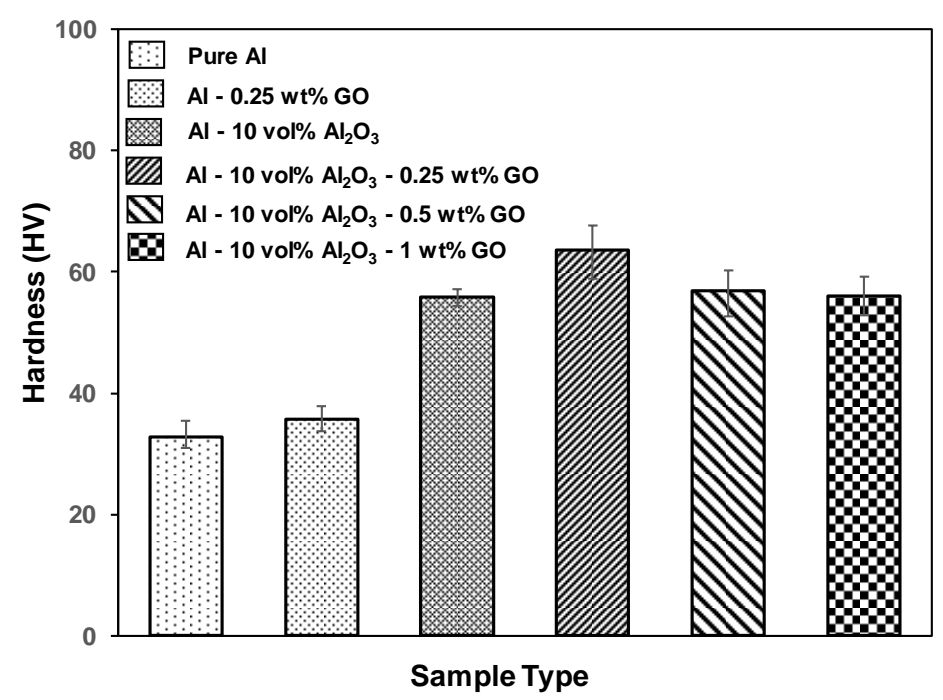

Figure 1. Variation of the hardness of $\mathrm{Al}$ nanocomposite and hybrid nanocomposites.

\subsection{Tribological Characterization of the Nanocomposite/Hybrid Samples}

3.2.1. Specific Wear Rate of the Developed Nanocomposite/Hybrid Samples

Figure 2 shows the variation in the specific wear rate of the various samples tested under an applied load of $3 \mathrm{~N}$ and a sliding speed of $0.1 \mathrm{~m} / \mathrm{s}$ for a duration of 5000 cycles corresponding to a sliding distance of $100 \mathrm{~m}$. The specific wear rate was calculated by the ratio of the total wear volume loss to the product of sliding distance and the applied load. The wear volume loss was estimated by the product of the wear area, measured by analyzing the 2D profiles of the wear tracks recorded by using a 3D optical profilometer and the circumference of the wear track. Figure 3 shows a few typical 2D profiles as measured by the 3D optical profilometer for each tested sample. According to Figure 2, the specific wear rate of the aluminum composites (Al- $0.25 \mathrm{wt} \% \mathrm{GO}$ and $\mathrm{Al}-10 \mathrm{Vol} \% \mathrm{Al}_{2} \mathrm{O}_{3}$ ) decreased as compared to pure aluminum, noting that the reduction in the specific wear rate for Al-10 $\mathrm{Vol} \% \mathrm{Al}_{2} \mathrm{O}_{3}$ was greater than that of $\mathrm{Al}-0.25 \mathrm{wt} \% \mathrm{GO}$. This could be attributed to the higher hardness of the $\mathrm{Al}-10 \mathrm{Vol} \% \mathrm{Al}_{2} \mathrm{O}_{3}$ composite compared with that of the $\mathrm{Al}-0.25 \mathrm{wt} \% \mathrm{GO}$ composite, as reported in Figure 1.

For the hybrid nanocomposites, the specific wear rate decreased slightly further upon adding $0.25 \mathrm{wt} \% \mathrm{GO}$ to $\mathrm{Al}-10 \mathrm{Vol} \% \mathrm{Al}_{2} \mathrm{O}_{3}$, owing to the improved hardness of the hybrid nanocomposite (Figure 1), mainly due to the hard alumina nanoparticles, and to the lubricious nature of GO. Moreover, as reported earlier [44], for the hybrid nanocomposite Al-10 $\mathrm{Vol}_{\%} \mathrm{Al}_{2} \mathrm{O}_{3}-0.25 \mathrm{wt} \% \mathrm{GO}$, uniform dispersion of both reinforcements within the aluminum matrix was observed, leading to an effective load transfer, which reults in an improvement in the wear resistance. However, as the content of GO increased (0.5 and 1 $\mathrm{wt} \%$ ), the specific wear rate of the hybrid nanocomposites increased significantly. This could 
be attributed to the reduction in hardness of the samples (Figure 1), lower densification (Table 1), and as reported earlier [44], the formation of agglomerates of the reinforcements within the aluminum matrix.

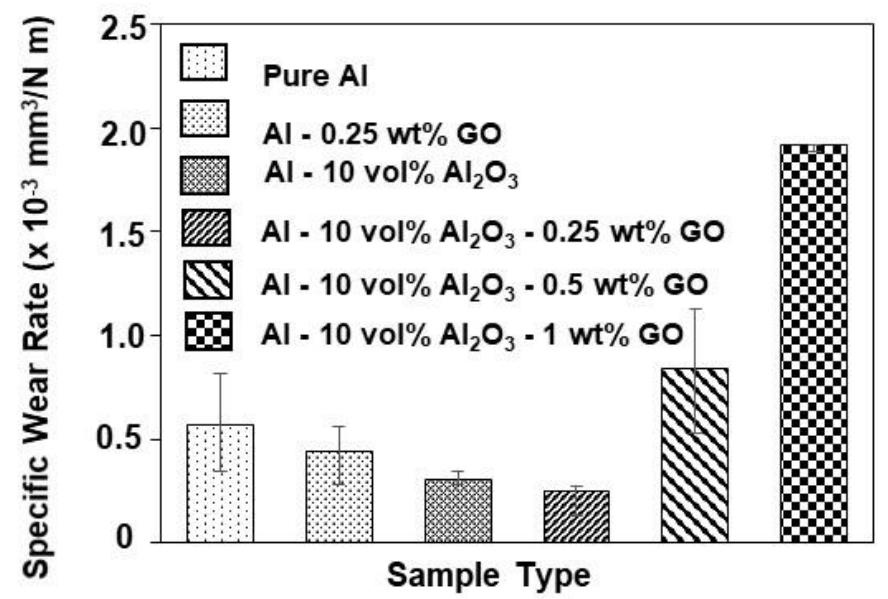

Figure 2. Variation of specific wear rate of different samples at a load of $3 \mathrm{~N}$, sliding speed of $0.1 \mathrm{~m} / \mathrm{s}$, and a sliding distance of $100 \mathrm{~m}$.

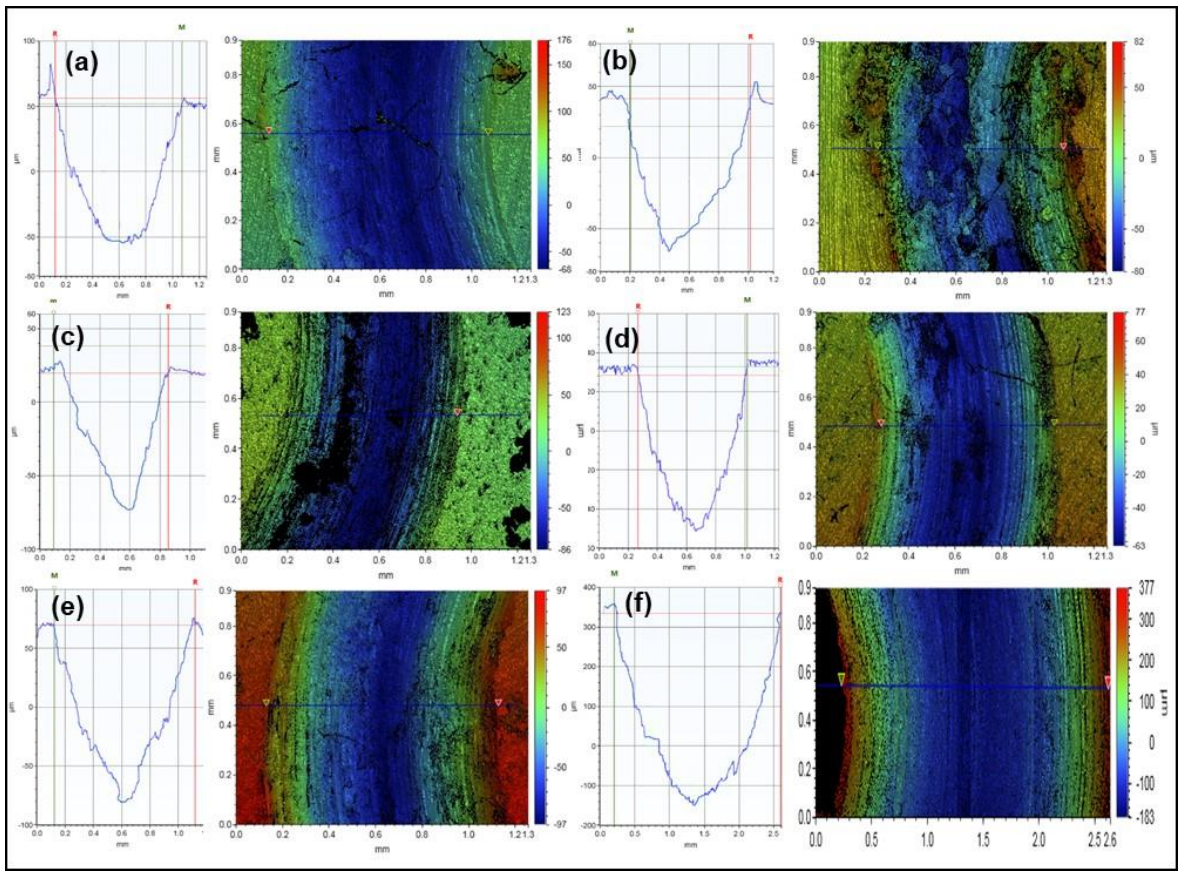

Figure 3. Typical 2D profiles for wear tracks after the wear test at a load of $3 \mathrm{~N}$, sliding speed of $0.1 \mathrm{~m} / \mathrm{s}$ and a sliding distance of $100 \mathrm{~m}$ : (a) Pure Al; (b) Al-0.25 wt\% GO; (c) Al-10 $\mathrm{Vol}_{\%} \mathrm{Al}_{2} \mathrm{O}_{3}$; (d) $\mathrm{Al}-10 \mathrm{Vol} \% \mathrm{Al}_{2} \mathrm{O}_{3}-0.25 \mathrm{wt} \% \mathrm{GO}$; (e) $\mathrm{Al}-10 \mathrm{Vol} \% \mathrm{Al}_{2} \mathrm{O}_{3}-0.5 \mathrm{wt} \% \mathrm{GO}$; (f) $\mathrm{Al}-10 \mathrm{Vol} \% \mathrm{Al}_{2} \mathrm{O}_{3}-1$ wt $\%$ GO.

\subsubsection{Friction Coefficient of the Developed Nanocomposites/Hybrid Samples}

Figures 4 and 5 show typical frictional graphs for the wear tests and the average coefficient of friction (COF) for all tested samples under a normal load of $3 \mathrm{~N}$, a sliding speed of $0.1 \mathrm{~m} / \mathrm{s}$, and a sliding distance of $100 \mathrm{~m}$. According to Figure 5, the average $\mathrm{COF}$ increased slightly for the $\mathrm{Al}-10 \mathrm{Vol} \% \mathrm{Al}_{2} \mathrm{O}_{3}$ nanocomposites compared with pure $\mathrm{Al}$, mainly due to the presence of the hard alumina particles. Moreover, the COF of Al-0.25 $\mathrm{wt} \% \mathrm{GO}$ was less than that of pure $\mathrm{Al}$ and the $\mathrm{Al}-10 \mathrm{Vol} \% \mathrm{Al}_{2} \mathrm{O}_{3}$ nanocomposite, due to the lubricious nature of GO. However, for the hybrid nanocomposite, Al-10 Vol $\% \mathrm{Al}_{2} \mathrm{O}_{3}-0.25$ 
$w \mathrm{t} \% \mathrm{GO}$, the COF increased slightly as compared with the Al- $0.25 \mathrm{wt} \% \mathrm{GO}$ nanocomposites, due to the addition of hard alumina particles. The COF for the $\mathrm{Al}-10 \mathrm{Vol} \% \mathrm{Al}_{2} \mathrm{O}_{3}-0.25 \mathrm{wt} \%$ $\mathrm{GO}$ hybrid nanocomposite was lower than pure $\mathrm{Al}$ and $\mathrm{Al}-10 \mathrm{Vol} \% \mathrm{Al}_{2} \mathrm{O}_{3}$ nanocomposites, due to the presence of lubricious GO. In fact, a further increase in the GO content led to a further decrease in COF. The main reason for adding GO to the hybrid nanocomposite was to reduce the COF, as confirmed by these results.

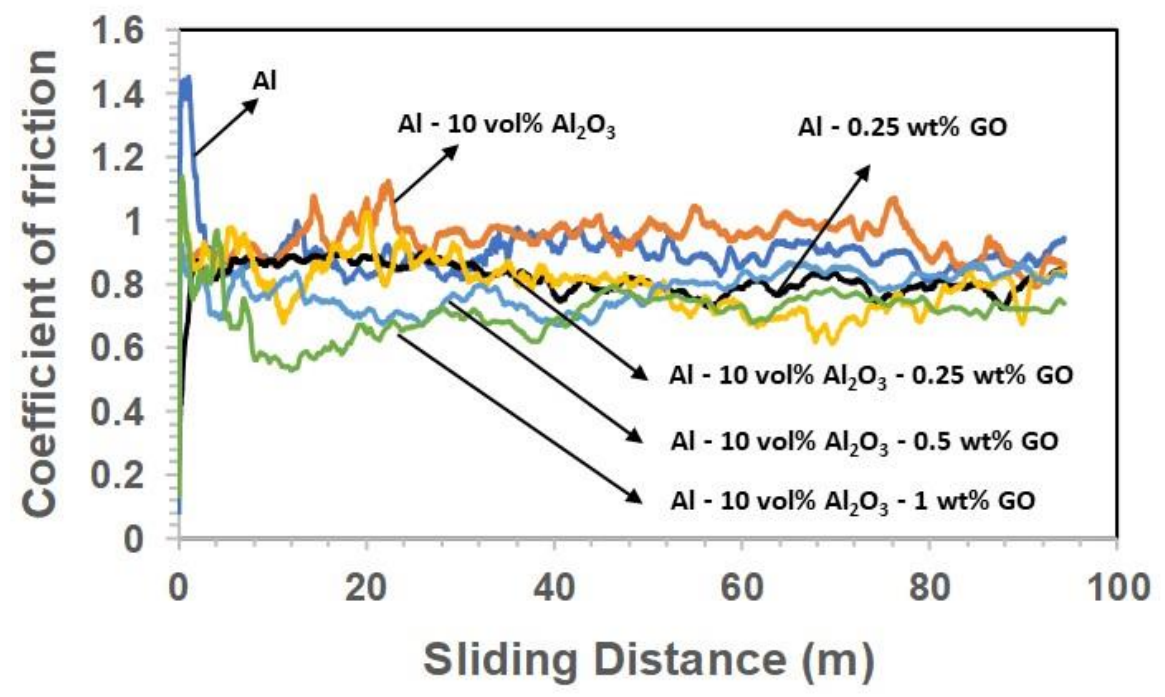

Figure 4. Typical frictional graphs for all the tested samples at a load of $3 \mathrm{~N}$, sliding speed of $0.1 \mathrm{~m} / \mathrm{s}$, and a sliding distance of $100 \mathrm{~m}$.

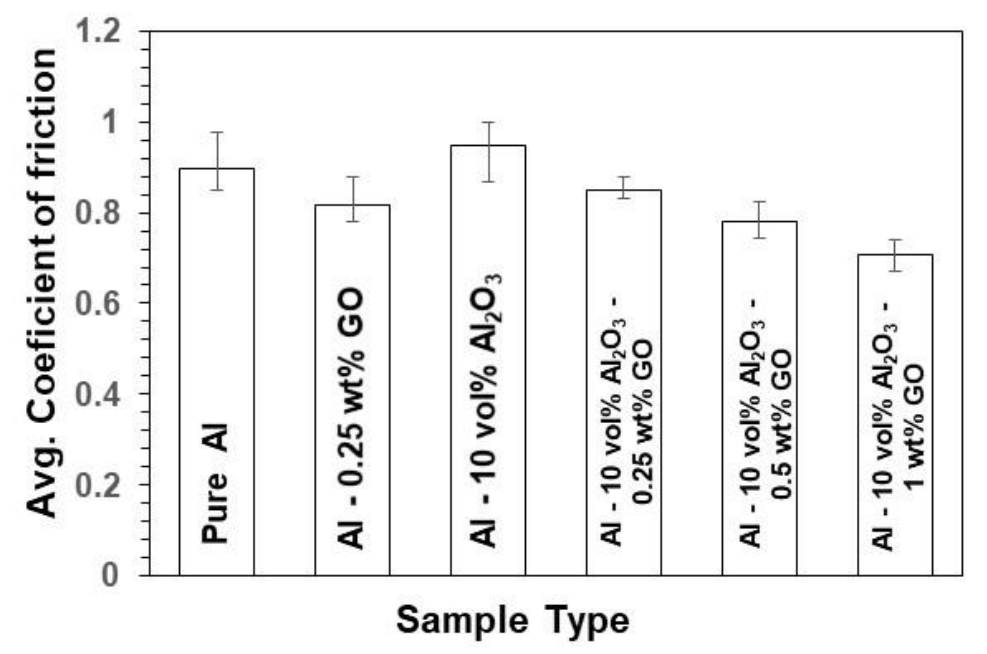

Figure 5. Variation of average coefficient of friction for all the tested samples at a load of $3 \mathrm{~N}$, sliding speed of $0.1 \mathrm{~m} / \mathrm{s}$, and a sliding distance of $100 \mathrm{~m}$.

\subsubsection{SEM/EDS Analysis}

Figure 6 shows the SEM/EDS images of the wear tracks, and Figure 7 shows the optical images of the counterface ball after sliding against the tested samples at a load of $3 \mathrm{~N}$, sliding speed of $0.1 \mathrm{~m} / \mathrm{s}$, and for a sliding distance of $100 \mathrm{~m}$.

Pure Al displayed a high wear rate, as shown in Figure 2, and was confirmed by SEM image of the wear track shown in Figure 6a. It shows a very rough surface characterized by deep grooves and debris particles resulting from the ploughing of the surface during the wear test involving a two-body and a three-body abrasive wear mechanism coupled with severe adhesive wear (gouging) mechanism (Figure 6a). The high COF of 0.9 shown by $\mathrm{Al}$ (Figure 5) was attributed to the high adhesive and the deformation components of the 
friction coefficient. The counterface ball sliding against the samples also showed a large scar mark, as shown in Figure 7a.
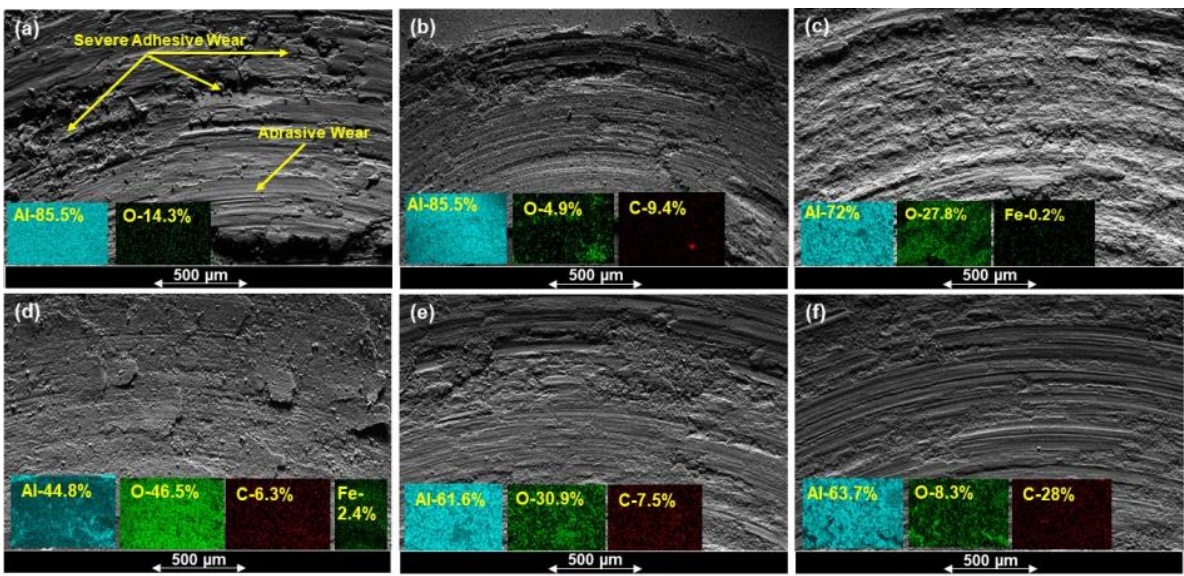

Figure 6. Typical SEM images and EDS mapping for the wear tracks of (a) Pure Al (b) Al- $0.25 \%$ wt $\%$ GO (c) $\mathrm{Al}-10 \mathrm{Vol}_{\%} \mathrm{Al}_{2} \mathrm{O}_{3}$ (d) $\mathrm{Al}-10 \mathrm{Vol} \% \mathrm{Al}_{2} \mathrm{O}_{3}-0.25 \mathrm{wt} \% \mathrm{GO}$ (e) $\mathrm{Al}-10 \mathrm{Vol} \% \mathrm{Al}_{2} \mathrm{O}_{3}-0.5 \mathrm{wt} \% \mathrm{GO}$ (f) $\mathrm{Al}-10 \mathrm{Vol} \% \mathrm{Al}_{2} \mathrm{O}_{3}-1 \mathrm{wt} \% \mathrm{GO}$, after the wear test at a load of $3 \mathrm{~N}$, sliding speed of $0.1 \mathrm{~m} / \mathrm{s}$, and a sliding distance of $100 \mathrm{~m}$.
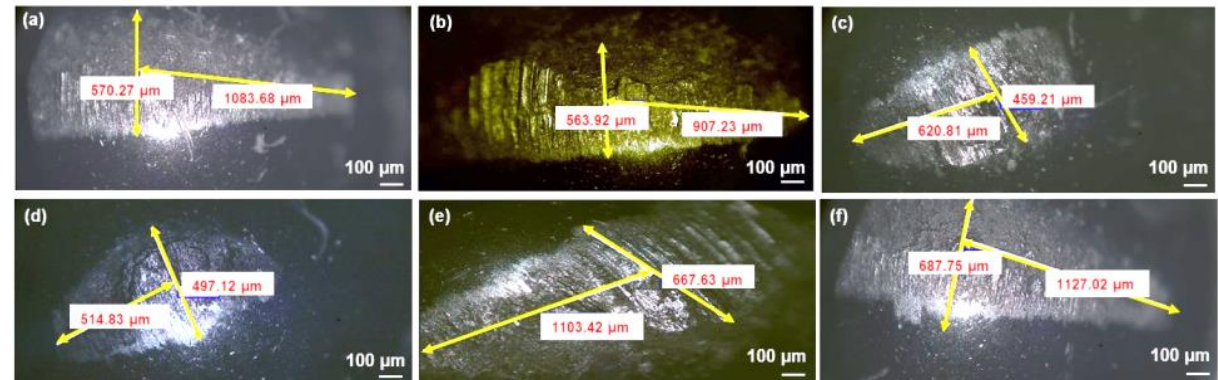

Figure 7. Typical optical counterface ball images sliding against: (a) Pure Al (b) Al-0.25 wt $\%$ GO (c) $\mathrm{Al}-10 \mathrm{Vol} \% \mathrm{Al}_{2} \mathrm{O}_{3}$ (d) $\mathrm{Al}-10 \mathrm{Vol} \% \mathrm{Al}_{2} \mathrm{O}_{3}-0.25 \mathrm{wt} \% \mathrm{GO}$ (e) $\mathrm{Al}-10 \mathrm{Vol} \% \mathrm{Al}_{2} \mathrm{O}_{3}-0.5 \mathrm{wt} \% \mathrm{GO}$ (f) $\mathrm{Al}-10$ $\mathrm{Vol} \% \mathrm{Al}_{2} \mathrm{O}_{3}-1 \mathrm{wt} \% \mathrm{GO}$, after the wear at a load of $3 \mathrm{~N}$, sliding speed of $0.1 \mathrm{~m} / \mathrm{s}$, and a sliding distance of $100 \mathrm{~m}$.

However, on the addition of $0.25 \mathrm{wt} \% \mathrm{GO}$ alone to the $\mathrm{Al}$ matrix, a reduction of $22 \%$ and $9 \%$ in the specific wear rate and the COF was observed, respectively. Figure $6 \mathrm{~b}$ shows a smoother wear track as compared with the pure $\mathrm{Al}$, with a few instances of adhesive wear along the edges. An increase in hardness was observed upon adding $0.25 \mathrm{wt} \% \mathrm{GO}$ to Al matrix (Figure 1), which could be the reason for its better tribological performance in terms of increased wear resistance. The inherent lubricating properties of GO must have contributed to the reduction in the COF as compared with Al. Moreover, the counterface ball sliding against the Al- $0.25 \mathrm{wt} \%$ GO also showed a scar mark of similar size, as shown by the ball sliding against the $\mathrm{Al}$ sample.

The addition of $10 \mathrm{Vol} \% \mathrm{Al}_{2} \mathrm{O}_{3}$ alone to $\mathrm{Al}$ matrix resulted in a significant increase in the hardness, as shown in Figure 1 . The $\mathrm{Al}-10 \mathrm{Vol}_{\%} \mathrm{Al}_{2} \mathrm{O}_{3}$ composite showed a significant decrease of $46 \%$ in the specific wear rate, accompanied by a $6 \%$ increase in the COF as compared with Al (Figures 2 and 5). A close examination of the wear track showed the wear mechanism to be mostly abrasive in nature, with ploughing marks visible in the direction of sliding. Small traces of iron were detected on the wear track, which could have been transferred from the counterface ball during the test (Figure 6c). The scar mark on the counterface ball was slightly smaller (Figure 7c) compared with the one observed in the earlier cases. Thus, it can be inferred that the addition of $\mathrm{Al}_{2} \mathrm{O}_{3}$ to $\mathrm{Al}$ matrix contributed 
mainly to the improvement of the hardness of $\mathrm{Al}$, leading to a significant decrease in the specific wear rate.

Upon adding both reinforcements to $\mathrm{Al}$ matrix to form a hybrid nanocomposite, an interesting trend was observed. A simultaneous addition of $10 \mathrm{Vol} \% \mathrm{Al}_{2} \mathrm{O}_{3}$ and $0.25 \mathrm{wt} \%$ GO to $\mathrm{Al}$ resulted in an increase of $48 \%$ in the hardness, reduction of $55 \%$ in the specific wear rate and a reduction of 5\% in COF compared with Al. Moreover, this hybrid nanocomposite exhibited a better wear resistance than $\mathrm{Al}-0.25 \mathrm{wt} \% \mathrm{GO}$ and $\mathrm{Al}-10 \mathrm{Vol} \% \mathrm{Al}_{2} \mathrm{O}_{3}$ composites (Figure 2). The SEM image analysis of the wear track revealed a smooth surface with traces of wear predominantly by plastic deformation. Moreover, the scar mark on the counterface ball was also relatively small compared with the other samples (Figure 7d). This excellent performance of the $\mathrm{Al}-10 \mathrm{Vol} \% \mathrm{Al}_{2} \mathrm{O}_{3}-0.25 \mathrm{wt} \% \mathrm{GO}$ could be attributed to the improvement in the hardness due to the addition of both $\mathrm{Al}_{2} \mathrm{O}_{3}$ and $\mathrm{GO}$ particles, with the major contribution coming from the hard $\mathrm{Al}_{2} \mathrm{O}_{3}$ particles. The $\mathrm{GO}$ contributed to the reduction in the COF of the hybrid nanocomposite by forming a tribo film over the wear track, as revealed by EDS analysis of the wear track (Figure 6d).

A further increase in GO content (0.5 and $1 \mathrm{wt} \%$ ) in $\mathrm{Al}-10 \mathrm{Vol} \% \mathrm{Al}_{2} \mathrm{O}_{3}$ matrix resulted in a reduction in hardness, wear resistance and COF. The decrease in the hardness and density of the hybrid samples with the increased amount of GO was attributed to the formation of GO agglomerates, as reported in [44]. The formation of GO agglomerates resulted in a two-phase morphology, leading to a decrease in hardness, which in turn reduced the wear resistance of these hybrid samples (Figure 2). The examination of the SEM images of the wear track, performed after the wear test, indicated the primary wear mechanism to be abrasive wear due to ploughing, as groove marks were visible in the direction of sliding (Figure 6e,f). The scar marks on the counterface balls were also more significant than the balls that slid against the other samples (Figure 7e,f).

\section{Summary and Comparative Analysis}

Table 3 summarizes the results obtained in the current study for all tested samples in terms of relative density, hardness, wear rate and coefficient of friction. Clearly, Al-10 Vol\% $\mathrm{Al}_{2} \mathrm{O}_{3}-0.25 \mathrm{wt} \% \mathrm{GO}$ nanocomposite showed the highest reduction of $55.65 \%$ in specific wear rate compared with $\mathrm{Al}$.

Table 3. Summary of the results obtained in the current study.

\begin{tabular}{|c|c|c|c|c|c|c|}
\hline \multirow[b]{2}{*}{ Property } & \multicolumn{6}{|c|}{ Sample } \\
\hline & Al & $\begin{array}{c}\mathrm{Al}+0.25 w \mathrm{t} \% \\
\text { GO }\end{array}$ & $\begin{array}{c}\mathrm{Al}+10 \mathrm{Vol} \% \\
\mathrm{Al}_{2} \mathrm{O}_{3}\end{array}$ & $\begin{array}{c}\mathrm{Al}+10 \mathrm{Vol} \% \\
\mathrm{Al}_{2} \mathrm{O}_{3}+ \\
0.25 \mathrm{wt} \% \mathrm{GO}\end{array}$ & $\begin{array}{c}\mathrm{Al}+10 \mathrm{Vol} \% \\
\mathrm{Al}_{2} \mathrm{O}_{3}+ \\
0.5 \mathrm{wt} \% \mathrm{GO}\end{array}$ & $\begin{array}{c}\mathrm{Al}+10 \mathrm{Vol} \% \\
\mathrm{Al}_{2} \mathrm{O}_{3}+1 \mathrm{wt} \% \\
\text { GO }\end{array}$ \\
\hline Hardness (HV) & 32.8 & 35.76 & 55.8 & 63.56 & 56.9 & 56 \\
\hline Relative density (\%) & 99.8 & 99.2 & 99.5 & 98.9 & 98.6 & 97.4 \\
\hline $\begin{array}{l}\text { Specific Wear Rate } \\
\left(10^{-6} \mathrm{~mm}^{3} / \mathrm{Nm}\right)\end{array}$ & 566 & 439 & 303 & 251 & 837 & 1920 \\
\hline Reduction in Wear Rate (\%) & 0 & 22.63 & 46.37 & 55.65 & -47.87 & -238.8 \\
\hline
\end{tabular}

Furthermore, the tribological performance of the $\mathrm{Al}-10 \mathrm{Vol} \% \mathrm{Al}_{2} \mathrm{O}_{3}-0.25 \mathrm{wt} \% \mathrm{GO}$ sample showed the lowest wear rate in the current study, as compared with the results reported in the literature. Table 4 compares the tribological performance of the aluminum composites reinforced with $\mathrm{Al}_{2} \mathrm{O}_{3}$ and graphene, as reported in the literature, with the hybrid nanocomposite developed in the current study. It is worth noting that the developed aluminum hybrid nanocomposite reinforced with both $\mathrm{Al}_{2} \mathrm{O}_{3}$ and $\mathrm{GO}$ showed excellent tribological performance as compared with the performance of the composites reported in the literature. 
Table 4. Comparative analysis of the results reports in the literature related to Al-based composites.

\begin{tabular}{|c|c|c|c|c|c|c|}
\hline Composite & $\begin{array}{l}\text { Fabrication } \\
\text { Method }\end{array}$ & $\begin{array}{c}\text { Relative } \\
\text { Density (\%) }\end{array}$ & Hardness & Wear & $\begin{array}{l}\text { Reduction in } \\
\text { Wear Rate \% }\end{array}$ & Ref \\
\hline Al-6082 & \multirow{4}{*}{ Stir Casting } & 98.3 & $74 \mathrm{BHN}$ & $62 \mu \mathrm{g}$ & 0 & \multirow{4}{*}[45]{} \\
\hline $\mathrm{Al}-6082+10 \% \mathrm{Al}_{2} \mathrm{O}_{3}$ & & 97.5 & $78 \mathrm{BHN}$ & $45 \mu \mathrm{g}$ & $27.41 \%$ & \\
\hline $\mathrm{Al}-6082+15 \% \mathrm{Al}_{2} \mathrm{O}_{3}$ & & 97.3 & $81 \mathrm{BHN}$ & $35 \mu \mathrm{g}$ & $43.35 \%$ & \\
\hline $\mathrm{Al}-6082+20 \% \mathrm{Al}_{2} \mathrm{O}_{3}$ & & 96.9 & $87 \mathrm{BHN}$ & $30 \mu \mathrm{g}$ & $51.61 \%$ & \\
\hline $\mathrm{Al} 6061$ & \multirow{4}{*}{ Stir Casting } & -- & $95 \mathrm{HV}$ & $0.035 \mathrm{gm}$ & 0 & \multirow{4}{*}[46]{} \\
\hline $\mathrm{Al} 6061+6 \% \mathrm{Al}_{2} \mathrm{O}_{3}$ & & -- & $105 \mathrm{HV}$ & $0.028 \mathrm{gm}$ & $20 \%$ & \\
\hline $\mathrm{Al} 6061+9 \% \mathrm{Al}_{2} \mathrm{O}_{3}$ & & -- & $150 \mathrm{HV}$ & $0.023 \mathrm{gm}$ & $34.28 \%$ & \\
\hline $\mathrm{Al}-6061+12 \% \mathrm{Al}_{2} \mathrm{O}_{3}$ & & -- & $188 \mathrm{HV}$ & $0.020 \mathrm{gm}$ & $42.85 \%$ & \\
\hline Al-6061 & \multirow{4}{*}{ Stir Casting } & -- & $28 \mathrm{BHN}$ & $1.4 \times 10^{-3}\left(\mathrm{~mm}^{3} / \mathrm{m}\right)$ & 0 & \multirow{4}{*}[47]{} \\
\hline $\mathrm{Al}-6061-5 \% \mathrm{Al}_{2} \mathrm{O}_{3}$ & & -- & $33 \mathrm{BHN}$ & $0.9 \times 10^{-3}\left(\mathrm{~mm}^{3} / \mathrm{m}\right)$ & $35.71 \%$ & \\
\hline $\mathrm{Al}-6061-10 \% \mathrm{Al}_{2} \mathrm{O}_{3}$ & & -- & $38 \mathrm{BHN}$ & $0.64 \times 10^{-3}\left(\mathrm{~mm}^{3} / \mathrm{m}\right)$ & $54.42 \%$ & \\
\hline $\mathrm{Al}-6061-15 \% \mathrm{Al}_{2} \mathrm{O}_{3}$ & & -- & $39 \mathrm{BHN}$ & $0.66 \times 10^{-3}\left(\mathrm{~mm}^{3} / \mathrm{m}\right)$ & $52.85 \%$ & \\
\hline $\mathrm{Al}$ & \multirow{3}{*}{$\begin{array}{l}\text { Powder } \\
\text { Metallurgy }\end{array}$} & 98 & $111 \mathrm{HV}$ & $0.006(\mathrm{~g})$ & 0 & \multirow{3}{*}[48]{} \\
\hline $\mathrm{Al}+0.1 \mathrm{wt} \% \mathrm{GNP}$ & & 98.8 & $98 \mathrm{HV}$ & $0.005(\mathrm{~g})$ & $16.66 \%$ & \\
\hline $\mathrm{Al}+1 \mathrm{wt} \% \mathrm{GNP}$ & & 98.8 & $97 \mathrm{HV}$ & $0.007(\mathrm{~g})$ & $-16.66 \%$ & \\
\hline $\mathrm{Al} 7075$ & \multirow{2}{*}{$\begin{array}{l}\text { Spark Plasma } \\
\text { Sintering }\end{array}$} & 99 & $96.8 \mathrm{HV}$ & $0.0034\left(\mathrm{~mm}^{3} / \mathrm{m}\right)$ & 0 & \multirow{2}{*}{ [49] } \\
\hline Al-7075/GNPs & & 99 & $124.9 \mathrm{HV}$ & $0.00275\left(\mathrm{~mm}^{3} / \mathrm{m}\right)$ & $19.11 \%$ & \\
\hline $\mathrm{A} 356$ & \multirow{4}{*}{$\begin{array}{c}\text { Stir and } \\
\text { squeeze casting }\end{array}$} & -- & -- & 44 Vol loss $\left(\mathrm{mm}^{3}\right)$ & 0 & \multirow{4}{*}[50]{} \\
\hline $\mathrm{A} 356-0.5 \% \mathrm{Al}_{2} \mathrm{O}_{3}$ & & -- & -- & 27 Vol loss $\left(\mathrm{mm}^{3}\right)$ & $38.63 \%$ & \\
\hline $\mathrm{A} 356-1 \% \mathrm{Al}_{2} \mathrm{O}_{3}$ & & -- & -- & 25 Vol loss $\left(\mathrm{mm}^{3}\right)$ & $43.18 \%$ & \\
\hline $\mathrm{A} 356-1.5 \% \mathrm{Al}_{2} \mathrm{O}_{3}$ & & -- & -- & 32 Vol loss $\left(\mathrm{mm}^{3}\right)$ & $27.27 \%$ & \\
\hline $\mathrm{Al}$ & \multirow{6}{*}{$\begin{array}{l}\text { Sintering } \\
\text { Process }\end{array}$} & -- & $53 \mathrm{HRB}$ & $0.039(\mathrm{~g})$ & 0 & \multirow{6}{*}[51]{} \\
\hline $\mathrm{Al}+0.01$ wt\%Greaphene & & -- & $54 \mathrm{HRB}$ & $0.037(\mathrm{~g})$ & $5.12 \%$ & \\
\hline $\mathrm{Al}+0.5$ wt\%Greaphene & & -- & $62 \mathrm{HRB}$ & $0.021(\mathrm{~g})$ & 46.15 & \\
\hline $\mathrm{Al}+1 \mathrm{wt} \%$ Greaphene & & -- & $58 \mathrm{HRB}$ & $0.055(\mathrm{~g})$ & $-41.02 \%$ & \\
\hline $\mathrm{Al}+2 \mathrm{wt} \%$ Greaphene & & -- & $49 \mathrm{HRB}$ & $0.105(\mathrm{~g})$ & $-169.23 \%$ & \\
\hline $\mathrm{Al}+5 \mathrm{wt} \%$ Greaphene & & -- & $45 \mathrm{HRB}$ & $0.170(\mathrm{~g})$ & $-335.89 \%$ & \\
\hline AA 6061 & \multirow{5}{*}{$\begin{array}{l}\text { Microwave } \\
\text { sintering }\end{array}$} & -- & $65 \mathrm{HV}$ & 0.075 (gms) & 0 & \multirow{5}{*}[52]{} \\
\hline AA $6061+0.3 \%$ Graphene & & -- & $77 \mathrm{HV}$ & 0.062 (gms) & $17.33 \%$ & \\
\hline AA $6061+0.6 \%$ Graphene & & -- & $75 \mathrm{HV}$ & 0.062 (gms) & $17.33 \%$ & \\
\hline AA $6061+0.9 \%$ Graphene & & -- & $73 \mathrm{HV}$ & 0.066 (gms) & $12 \%$ & \\
\hline AA $6061+1.2 \%$ Graphene & & -- & $71 \mathrm{HV}$ & 0.070 (gms) & $6.66 \%$ & \\
\hline Al-2024 & \multirow{5}{*}{ Stir Casting } & -- & -- & $0.109(\mathrm{~g})$ & 0 & \multirow{5}{*}[53]{} \\
\hline Al-2024 + 0.25 wt\% Graphene & & -- & -- & $0.104(\mathrm{~g})$ & $4.58 \%$ & \\
\hline Al-2024 + 0.50 wt\% Graphene & & -- & -- & $0.0998(\mathrm{~g})$ & $8.44 \%$ & \\
\hline Al-2024 + 0.75 wt\% Graphene & & -- & -- & $0.0942(\mathrm{~g})$ & $13.57 \%$ & \\
\hline Al-2024 + 1 wt\% Graphene & & -- & -- & $0.0892(\mathrm{~g})$ & $18.16 \%$ & \\
\hline $\mathrm{Al}-0.25 \mathrm{wt} \% \mathrm{GO}-10 \mathrm{Vol} \% \mathrm{Al}_{2} \mathrm{O}_{3}$ & $\begin{array}{l}\text { Spark Plasma } \\
\text { Sintering }\end{array}$ & 98.9 & $63.56 \mathrm{HV}$ & $251 \times 10^{-6} \mathrm{~mm}^{3} / \mathrm{Nm}$ & $55.65 \%$ & $\begin{array}{l}\text { Present } \\
\text { Study }\end{array}$ \\
\hline
\end{tabular}

\section{Conclusions}

Aluminum ( $\mathrm{Al}$ ) hybrid nanocomposites were fabricated using the spark plasma sintering technique. Alumina $\left(\mathrm{Al}_{2} \mathrm{O}_{3}\right)$ and graphene oxide $(\mathrm{GO})$ were used to reinforce the $\mathrm{Al}$ matrix. The tribological performance of the developed nanocomposites was evaluated. The following conclusions can be drawn from the study:

- $\mathrm{Al}-10 \mathrm{Vol} \% \mathrm{Al}_{2} \mathrm{O}_{3}-0.25 \mathrm{wt} \% \mathrm{GO}$ hybrid nanocomposite showed the maximum increase in hardness of $48.4 \%$ compared with Al. This significant increase was attributed to the 
inherent hard nature of $\mathrm{Al}_{2} \mathrm{O}_{3}$ nanoparticles and the uniform dispersion of both the reinforcements within the $\mathrm{Al}$ matrix.

- $\mathrm{Al}-10 \mathrm{Vol} \% \mathrm{Al}_{2} \mathrm{O}_{3}-0.25 \mathrm{wt} \%$ GO hybrid nanocomposite showed the lowest specific wear rate. It exhibited the highest reduction of about $55.6 \%$ in the specific wear rate as compared with Al. This was attributed to the enhancement in the mechanical properties due to the reinforcements.

- The most predominant wear mechanism was found to be abrasive wear due to plastic deformation, with smooth surface characteristics of the wear track with significantly fewer debris particles. The scar mark on the counterface ball sliding against the Al-10 $\mathrm{Vol} \% \mathrm{Al}_{2} \mathrm{O}_{3}-0.25 \mathrm{wt} \% \mathrm{GO}$ hybrid nanocomposite was also the smallest.

Author Contributions: Conceptualization, methodology, funding acquisition, project administration, supervision, validation, writing — original draft preparation, writing—review and editing, A.S.M. Formal analysis, Investigation, data curation, O.S.A. Investigation, writing-review and editing, A.S.H. Methodology, writing-review and editing, T.L. Data curation, writing-review and editing, F.P. Data curation, validation, M.M.A.B. All authors have read and agreed to the published version of the manuscript.

Funding: The authors gratefully acknowledge the financial support provided by the Deanship of Scientific Research (DSR) at King Fahd University of Petroleum \& Minerals (KFUPM) through Project No. IN151009.

Institutional Review Board Statement: Not applicable.

Informed Consent Statement: Not applicable.

Data Availability Statement: Not applicable.

Conflicts of Interest: The authors declare no conflict of interest.

\section{References}

1. Clyne, T.W.; Withers, P.J. An Introduction to Metal Matrix Composites; Cambridge University Press: Cambridge, UK, 1993. [CrossRef]

2. Kainer, K.U. Metal Matrix Composites: Custom-Made Materials for Automotive and Aerospace Engineering; John Wiley \& Sons: Chichester, UK, 2006; p. 314.

3. Lloyd, D.J. Particle reinforced aluminum and magnesium matrix composites. Int. Mater. Rev. 1994, 39, 1-23. [CrossRef]

4. Lee, J.M.; Lee, S.K.; Hong, S.J.; Kwon, Y.N. Microstructures and thermal properties of A356/SiCp composites fabricated by liquid pressing method. Mater. Des. 2012, 37, 313-316. [CrossRef]

5. Alidokht, S.A.; Zadeh, A.A.; Soleymani, S.; Assadi, H. Microstructure and tribological performance of an aluminum alloy based hybrid composite produced by friction stir processing. Mater. Des. 2011, 32, 2727-2733. [CrossRef]

6. Torralba, J.; da Costa, C.; Velasco, F.J. P/M aluminum matrix composites: An overview. J. Mater. Process. Technol. 2003, 133, 203-206. [CrossRef]

7. Chakrapani, P.; Suryakumari, T.S.A. Mechanical properties of aluminium metal matrix composites-A review. Mater. Today Proc. 2021, 45, 5960-5964. [CrossRef]

8. Dursun, T.; Soutis, C. Recent developments in advanced aircraft aluminium alloys. Mater. Des. 2013, 56, 862-871. [CrossRef]

9. Sevik, H.; Kurnaz, S.C. Properties of alumina particulate reinforced aluminum alloy produced by pressure die casting. Mater. Des. 2005, 27, 676-683. [CrossRef]

10. Freitas, B.J.M.; Junior, A.M.J.; Zepon, G.; Kiminami, C.S.; Botta, W.J.; Bolfarini, C. Outstanding Tensile Ductility in High Iron-Containing Al-Si-Cu Alloys. Met. Mater. Trans. A 2020, 51, 2703-2710. [CrossRef]

11. Hutchinson, C.R.; Ringer, S.P. Precipitation processes in Al-Cu-Mg alloys microalloyed with Si. Met. Mater. Trans. A 2000, 31, 2721-2733. [CrossRef]

12. Dev, S.P.; Charoo, M.S. Aluminum metal matrix composites a review of reinforcement; Mechanical and tribological behavior. Int. J. Eng. Technol. 2018, 7, 117.

13. Tjong, S.C. Processing and Deformation Characteristics of Metals Reinforced with Ceramic Nanoparticles, 2nd ed.; Tjong, J., Ed.; Elsevier: Oxford, UK, 2014; pp. 269-304.

14. Tham, L.; Gupta, M.; Cheng, L. Effect of limited matrix-reinforcement interfacial reaction on enhancing the mechanical properties of aluminium-silicon carbide composites. Acta Mater. 2001, 49, 3243-3253. [CrossRef]

15. Rana, R.; Purohit, R.; Soni, V.; Das, S. Characterization of Mechanical Properties and Microstructure of Aluminium Alloy-SiC Composites. Mater. Today Proc. 2015, 2, 1149-1156. [CrossRef]

16. Song, M. Effects of volume fraction of SiC particles on mechanical properties of SiC/ Al composites. Trans. Nonferrous Met. Soc. China 2009, 19, 1400-1404. [CrossRef] 
17. Kumar, C.A.V.; Rajadurai, J.S. Influence of rutile (TiO2) content on wear and microhardness characteristics of aluminium-based hybrid composites synthesized by powder metallurgy. Trans. Nonferrous Met. Soc. China 2016, 26, 63-73. [CrossRef]

18. Ezatpour, H.; Torabi-Parizi, M.; Sajjadi, S.A. Microstructure and mechanical properties of extruded Al/Al2O3 composites fabricated by stir-casting process. Trans. Nonferrous Met. Soc. China 2013, 23, 1262-1268. [CrossRef]

19. Zahid, G.; Azhar, T.; Musaddiq, M.; Rizvi, S.; Ashraf, M.; Hussain, N.; Iqbal, M. In situ processing and aging behaviour of an aluminium/Al2O3 composite. Mater. Des. 2011, 32, 1630-1635. [CrossRef]

20. Razavi-Tousi, S.; Yazdani-Rad, R.; Manafi, S. Effect of volume fraction and particle size of alumina reinforcement on compaction and densification behavior of $\mathrm{Al}-\mathrm{Al}_{2} \mathrm{O}_{3}$ nanocomposites. Mater. Sci. Eng. A 2010, 528, 1105-1110. [CrossRef]

21. Jiang, X.-S.; Wang, N.-J.; Zhu, D.-G. Friction and wear properties of in-situ synthesized $\mathrm{Al}_{2} \mathrm{O}_{3}$ reinforced aluminum composites. Trans. Nonferrous Met. Soc. China 2014, 24, 2352-2358. [CrossRef]

22. Rahimian, M.; Parvin, N.; Ehsani, N. The effect of production parameters on microstructure and wear resistance of powder metallurgy Al-A12O3 composite. Mater. Des. 2010, 32, 1031-1038. [CrossRef]

23. Shuvho, M.; Chowdhury, M.; Kchaou, M.; Roy, B.; Rahman, A.; Islam, M. Surface characterization and mechanical behavior of aluminum based metal matrix composite reinforced with nano $\mathrm{Al}_{2} \mathrm{O}_{3}, \mathrm{SiC}, \mathrm{TiO}_{2}$ particles. Chem. Data Collect. 2020, $28,100442$. [CrossRef]

24. Kumar, N.; Chittappa, H.C.; Ezhil Vannan, S. Development of Aluminium-Nickel Coated Short Carbon Fiber Metal Matrix Composites. Mater. Today Proc. 2018, 5, 11336-11345. [CrossRef]

25. Wang, S.; Zhang, Y.; Sun, P.; Cui, Y.; Wu, G. Microstructure and Flexural Properties of Z-Pinned Carbon Fiber-Reinforced Aluminum Matrix Composites. Materials 2019, 12, 174. [CrossRef] [PubMed]

26. Sharma, P.; Sharma, S.; Khanduja, D. Effect of graphite reinforcement on physical and mechanical properties of alu-minum metal matrix composites. Part. Sci. Technol. 2016, 34, 17-22. [CrossRef]

27. Schrecengost, T.R.; Shaw, B.A.; Wendt, R.G.; Moshier, W.C. Nonequilibrium Alloying of Graphite-Reinforced Aluminum Metal Matrix Composites. Corrosion 1993, 49, 842-849. [CrossRef]

28. Jagannatham, M.; Chandran, P.; Sankaran, S.; Haridoss, P.; Nayan, N.; Bakshi, S.R. Tensile properties of carbon nanotubes reinforced aluminum matrix composites: A review. Carbon 2020, 160, 14-44. [CrossRef]

29. Sridhar, I.; Narayanan, K.R. Processing and characterization of MWCNT reinforced aluminum matrix composites. J. Mater. Sci. 2009, 44, 1750-1756. [CrossRef]

30. Munir, K.; Wen, C.; Li, Y. Graphene nanoplatelets-reinforced magnesium metal matrix nanocomposites with superior mechanical and corrosion performance for biomedical applications. J. Magnes. Alloy. 2019, 8, 269-290. [CrossRef]

31. Pourmand, N.S.; Asgharzadeh, H. Aluminum Matrix Composites Reinforced with Graphene: A Review on Production, Microstructure, and Properties. Crit. Rev. Solid State Mater. Sci. 2019, 45, 289-337. [CrossRef]

32. Lian, W.; Mai, Y.; Wang, J.; Zhang, L.; Liu, C.; Jie, X. Fabrication of graphene oxide-Ti3AlC2 synergistically reinforced copper matrix composites with enhanced tribological performance. Ceram. Int. 2019, 45, 18592-18598. [CrossRef]

33. Dasari, B.; Morshed, M.; Nouri, J.M.; Brabazon, D.; Naher, S. Mechanical properties of graphene oxide reinforced aluminium matrix composites. Compos. Part B Eng. 2018, 145, 136-144. [CrossRef]

34. Şahin, Y. Tribological behavior and wear surface analysis of metal-matrix composites. J. Mater. Sci. 1999, 34, 875-880. [CrossRef]

35. Prabhakar, N.S.; Radhika, N.; Raghu, R. Analysis of Tribological Behavior of Aluminium/B ${ }_{4}$ C Composite Under Dry Sliding Motion. Procedia Eng. 2014, 97, 994-1003. [CrossRef]

36. Faisal, N.; Kumar, K. Mechanical and tribological behaviour of nano scaled silicon carbide reinforced aluminium composites. J. Exp. Nanosci. 2018, 13, S1-S13. [CrossRef]

37. Jiang, J.; Xiao, G.; Che, C.; Wang, Y. Microstructure, Mechanical Properties and Wear Behavior of the Rheoformed 2024 Aluminum Matrix Composite Component Reinforced by $\mathrm{Al}_{2} \mathrm{O}_{3}$ Nanoparticles. Metals 2018, 8, 460. [CrossRef]

38. Al-Qutub, A.; Allam, I.; Qureshi, T. Effect of sub-micron $\mathrm{Al}_{2} \mathrm{O}_{3}$ concentration on dry wear properties of 6061 aluminum based composite. J. Mater. Process. Technol. 2005, 172, 327-331. [CrossRef]

39. Ramachandra, M.; Abhishek, A.; Siddeshwar, P.; Bharathi, V. Hardness and Wear Resistance of $\mathrm{ZrO}_{2} \mathrm{Nano}$ Particle Reinforced Al Nanocomposites Produced by Powder Metallurgy. Procedia Mater. Sci. 2015, 10, 212-219. [CrossRef]

40. Kumar, A.; Arafath, Y.; Gupta, P.; Kumar, D.; Hussain, C.M.; Jamwal, A. Microstructural and mechano-tribological behavior of Al reinforced SiC-TiC hybrid metal matrix composite. Mater. Today Proc. 2020, 21, 1417-1420. [CrossRef]

41. Rengifo, S.; Zhang, C.; Harimkar, S.; Boesl, B.; Agarwal, A. Tribological Behavior of Spark Plasma Sintered Aluminum-Graphene Composites at Room and Elevated Temperatures. Technologies 2017, 5, 4. [CrossRef]

42. Singh, J. Fabrication characteristics and tribological behavior of Al/SiC/Gr hybrid aluminum matrix composites: A review. Friction 2016, 4, 191-207. [CrossRef]

43. Mosleh-Shirazi, S.; Akhlaghi, F.; Li, D.-Y. Effect of SiC content on dry sliding wear, corrosion and corrosive wear of Al/SiC nanocomposites. Trans. Nonferrous Met. Soc. China 2016, 26, 1801-1808. [CrossRef]

44. Mohammed, A.; Alahmari, T.; Laoui, T.; Hakeem, A.; Patel, F. Mechanical and Thermal Evaluation of Aluminum Hybrid Nanocomposite Reinforced with Alumina and Graphene Oxide. Nanomaterials 2021, 11, 1225. [CrossRef] [PubMed]

45. Ajit, S.D.; Jayakumar, J. Evaluation of mechanical and wear properties of aluminium- $\mathrm{Al}_{2} \mathrm{O}_{3}$ composite material. Int. Res. J. Eng. Technol. (IRJET) 2012, 5, 5-18. 
46. Bharath, V.; Madev, N.; Auradi, V.; Kori, S.A. Preparation of 6061Al- $\mathrm{Al}_{2} \mathrm{O}_{3} \mathrm{MMC}^{\prime}$ by Stir Casting and Evaluation of Mechanical and Wear Properties. Procedia Mater. Sci. 2014, 6, 1658-1667. [CrossRef]

47. Al-Salihi, H.A.; Judran, H.K. Effect of $\mathrm{Al}_{2} \mathrm{O}_{3}$ reinforcement nanoparticles on the tribological behaviour and mechanical properties of Al6061 alloy. AIMS Mater. Sci. 2020, 7, 486-498. [CrossRef]

48. Tabandeh, K.; Meysam, O.; Emad, M.; Pradeep, R. and Pradeep, K.H. Tribological performance of self-lubricating aluminum matrix nanocomposites: Role of graphene nanoplatelets. Eng. Sci. Technol. Int. J. 2016, 19, 463-469.

49. Xia, H.-M.; Zhang, L.; Zhu, Y.-C.; Li, N.; Sun, Y.-Q.; Zhang, J.-D.; Ma, H.-Z. Mechanical properties of graphene nanoplatelets reinforced 7075 aluminum alloy composite fabricated by spark plasma sintering. Int. J. Miner. Met. Mater. 2020, 27, 1295-1300. [CrossRef]

50. Sekar, K.; Allesu, K.; Joseph, M.A. Mechanical and Wear Properties of $\mathrm{Al}-\mathrm{Al}_{2} \mathrm{O}_{3}$ Metal Matrix Composites Fabricated by the Combined Effect of Stir and Squeeze Casting Method. Trans. Indian Inst. Met. 2015, 68, 115-121. [CrossRef]

51. Aswin, S.; Soney, V. Tribology study of graphene-aluminium nanocomposites. Int. J. Mech. Prod. Eng. (IJMPE) 2014, 2, 29-33.

52. Prashantha, K.H.G.; Anthony, X.M. Tribological Aspects of Graphene-Aluminum Nanocomposites; IntechOpen: London, UK, 2017. Available online: https:/ / www.intechopen.com/chapters/54209 (accessed on 1 December 2021). [CrossRef]

53. Srinivasa, M.R.; Rammohan, Y.S.; Karthik, U.N.; Sadashiva, A.N.D. Analysis on wear properties of graphene hydroxyl rein-forced aluminum composites. IJAST 2020, 29, 4162. 